\title{
EU refugee policies and politics in times of crisis: theoretical and empirical perspectives
}

(Date of acceptance: 8 September 2017, Journal of Common Market Studies, forthcoming $1 / 2018)$.

\section{Arne Niemann and Natascha Zaun}

\section{Introduction}

Phenomena such as civil war, protracted conflict, and deteriorating internal security, especially in the Middle East, Africa and Southern Asia, have triggered massive departures of civilian populations in recent years. The war in Syria alone has displaced over 5 million people (UNHCR, 2017a). While most of these forced migrants are either internally displaced or remain in Syria's immediate neighbourhood, the numbers of those trying to come to Europe have steeply increased in 2015 and 2016. In each of these two years more than 1.2 million asylum-seekers submitted their asylum claims in the EU (Eurostat, 2017a), as compared to 625,000 in 2014 (Eurostat, 2015, p. 4). This represents the largest inflow of asylum-seekers since World War II. Syria, Afghanistan and Iraq accounted for the largest share of those asylum-seekers that entered the EU in 2015 and 2016 (Eurostat, 2017b).

Despite the common perception that the doubling in asylum applications was the root cause of the ensuing situation of crisis in the EU (BBC New 2016a), it was only a trigger. In fact, the increase of applications only uncovered persistent dysfunctionalities and shortcomings of the Common European Asylum System (CEAS). The so-called European 'refugee crisis' should therefore more accurately be termed a crisis of the CEAS. ${ }^{1}$

A CEAS with common protection standards and a clear distribution mechanism had been introduced on paper in June 2013 through several EU directives and the Dublin III Regulation. Yet, the absence of such rules in practice became strikingly obvious since late summer 2015.

By spring 2015, the number of arrivals of asylum-seekers in Italy and Greece increased steeply. Both countries, which have relatively weak asylum systems, were thus overwhelmed and 'waived asylum-seekers through'. This resulted in enormous 'secondary movements' towards Northern Europe. Eventually, the Dublin system - according to which border countries are responsible for

\footnotetext{
${ }^{1}$ While generally all contributors agree that systemic factors rather than the increased inflow of asylum-seekers caused the crisis, authors use different wordings. For instance, Thielemann refers to it as the "Syrian refugee crisis", focusing on the ongoing Syrian war and humanitarian crisis. While this crisis is the main reason for increasing asylum applications in Europe, the crisis is located in Syria and not in Europe. Jachtenfuchs and Genschel use the term 'refugee crisis' as the term most commonly used in public debates. Slominski and Trauner refer to the crisis as the 'migration crisis' for similar reasons, yet, highlighting that, from the perspective of states, migrants usually only become refugees once they receive official refugee status.
} 
any asylum-seeker entering the Schengen area through their territory - broke down completely. In other words '[it] collapsed under its own weight' (Menéndez, 2016, p. 397).

With growing evidence that asylum-seekers were systematically detained and subject to degrading treatment in the by then top-recipient country Hungary, the German government unilaterally suspended the Dublin Regulation for Syrians in August 2015. Germany thereby admitting them into the national asylum system, irrespective of their first country of entry (Euractiv, 2015a). While the German chancellor had hoped that other Member States would follow her example, this expectation remained unfulfilled. One week later, she assured the German public that Germany could handle the large influx of refugees, saying "we can do this".

About two weeks later, the German government, pressured by a huge wave of arrivals in Bavaria, to some extents reversed its course by deciding to temporarily reinstate border controls at the internal Schengen border with Austria. This prompted a chain reaction, pushing several other EU countries, such as Austria, France, Denmark, and Sweden, to also introduce internal border controls in order to avoid becoming a "dead end" where "unwelcome' refugees could get 'stranded' (Pastore and Henry, 2016, p. 54). In October 2015, in response to the increased numbers of asylum-seekers and dissatisfied with EU efforts to coordinate external border control, Hungary took the drastic measure to erect a new fence along its borders to Croatia and Serbia. This step allowed Hungary to shift migration flows to neighbouring countries, particularly Slovenia (Trauner, 2016, p. 320). This eventually led to a complete closure of the 'Balkan route', compelling tens of thousands of people to get stuck in Greece where they often had to live under devastating conditions (Weber 2016, p. 38).

The deaths of thousands of migrants at Europe's external borders, and some of the measures taken in order to curb refugee flows to Europe, have cast doubts on the role of the EU as a promoter of human rights in the world. Meanwhile, the intense media attention and substantial politicization of the issue, along with the rise of populist forces, have put great pressure on the EU institutions and member governments to come up with solutions. Thus, the raison d'être, added-value and resilience of the European integration project have been increasingly called into question. Together with the Eurozone crisis, this crisis has the potential to seriously damage the overall project of EU integration. Against the background of 18 years of EU co-operation on asylum policies, the lack of a concerted approach in times of crisis is puzzling and leads us to assess the state of integration in this policy field.

The goal of this Special Issue is to provide a systematic assessment of the crisis. Given the fact that the crisis has only a recent history, contributions on this topic are limited so far. Most publications are either press reports (e.g. BBC News, 2016b; Kingsley, 2016), or policy papers 
(Collet, 2015) and provide rather descriptive accounts, leaving ample room for more scholarly and theoretically informed analysis of the many facets of the crisis. This Special Issue provides a first comprehensive analysis of this topic, bringing together leading scholars working at the intersection of European integration and refugee studies, who discuss the most pertinent aspects of the crisis in a conceptually informed manner and apply/probe key theoretical approaches to the sequence of events. This Special Issue seeks to make a substantial empirical and theoretical contribution. In empirical terms, it advances original evidence in order to deepen our understanding of the crisis and how it has been managed. In theoretical terms, the Special Issue develops established and new theoretical accounts to analyse, explain and normatively assess European policy-making at a critical juncture of the EU's history. Before we delineate the individual contributions of the Special Issue as well as its broader conceptual contribution, we will briefly summarize and assess the EU's response to the crisis.

\section{The EU response to the crisis ${ }^{2}$}

Although the EU seemed to be caught rather unprepared by the crisis (Vătăman, 2016, p. 545), EU institutions had focused on migration since spring 2015. In May 2015, the European Commission (2015a) had already presented its "European Agenda on Migration" which outlined both immediate measures to be taken in response to the crisis in the Mediterranean and steps to improve migration management in the coming years. In September 2015, the European Commission (2015b) put forward priority actions to implement the Agenda. This section outlines the proposed measures and, to some extent, reviews their state of implementation and, to a lesser extent, their appropriateness.

The following analysis focuses on measures responding to the arrival of asylum-seekers at the EU's external borders (through the introduction of hotspots), measures on responsibility-sharing ${ }^{3}$ (through relocation and resettlement), policies of externalization (the EU-Turkey Statement), the redefinition of who is in need and has a right to asylum (through the introduction of new safe countries of origin), the prevention of irregular migration (through border control and measures against trafficking and smuggling), and stopping the departure of refugees from their home and transit countries (through the introduction of trust funds).

\footnotetext{
2 This section draws on Pauly, Bank, Blöser, Niemann, and Zaun (2016).

${ }^{3}$ We have opted for the notion of responsibility-sharing instead of burden-sharing as it refrains from framing asylum-seekers and refugees as a burden (see also Zaun, this volume). Most contributors (Bauböck, Jachtenfuchs and Genschel, and Thielemann, all this volume) stick with the notion of burden-sharing, as they study the physical distribution of refugees as a case of collective action and public goods and prefer using the original terminology of this theoretical approach.
} 


\section{Internal dimension of the response - Hotspots}

The EU decided to assist those Member States that had been facing the highest numbers of refugees at its external borders, namely Greece and Italy. The so-called "hotspot approach" aims at supporting the Member States in question by deploying Migration Management Support Teams that operate in five key areas: establishing functional hotspots, implementing the relocation decisions, ensuring the effective return of migrants not entitled to international protection, improving border management and creating sufficient and adequate reception capacity. To fulfil these tasks, the EU agencies Frontex, the European Asylum Support Office (EASO), Europol, and Eurojust provide operational support on the ground in cooperation with local authorities. Other Member States are required to meet the demand of sufficient experts and equipment to support these Migration Management Support Teams.

The agencies' tasks are supposed to be complementary to each other and they shall assist the Member States with the registration, identification, finger-printing and debriefing of asylumseekers, as well as with return operations. EASO teams help to manage the high amount of asylum claims. Frontex provides support in organizing the return of irregular migrants whose applications for asylum have been dismissed. Europol and Eurojust assist EU Member States in detecting networks of human smugglers and traffickers. The EU agencies only perform on the basis of existing hotspot structures. Financially supported by the EU, the Member States have to provide the sufficient infrastructure by themselves. The Commission regularly provides recommendations on and assessments of Member States' Action Plans and their implementations, but leaves the execution to them. The pressure on the 'frontline' states to implement EU policy has increased. They may no longer ignore EU rules on registration and finger-printing as specified in the Eurodac Regulation if they intend to profit from the relocation scheme (Trauner, 2016, p. 320).

It seems that the hotspots - after substantially delayed construction and implementation - have considerably improved the rates of registration and finger-printing (Neville et al., 2016). However, there has been substantial criticism with regard to the hotspot approach and its implementation. For example: (1) the lack of a specific legal framework regulating the hotspot approach which challenges the fundamental rights of refugees (Menéndez 2016, p. 408); (2) the approach having failed to relieve the pressure from Greece and Italy as intended (ECRE et al., 2016), which may be partly due to Member States not deploying enough experts for the Support Teams (European Commission, 2016a); (3) the chaotic conditions and poor services as to medication, food supply and accommodation (Human Rights Watch, 2016); (4) inadequate, unfair and/or repressive measures towards asylum-seekers, especially since the EU-Turkey 
Statement: many newly arrived asylum-seekers have been kept in prolonged detention without access to asylum procedures and have received inaccurate or incomplete information on the latter, or have been swiftly returned (ECRE et al. 2016). Because of this practice, several NGOs left camps, which reportedly led to a worsening of conditions in the hotspots (Neville et al., 2016).

\section{Internal dimension of the response - Relocation and Resettlement}

The so-called "temporary emergency relocation scheme" was introduced in September 2015. Relocation refers to the transfer of persons in need of international protection from one EU Member State to another. The relocation scheme has been introduced to remedy the disproportionate responsibility put on those countries with EU external borders, particularly Greece and Italy. In the scheme, EU Member States committed themselves to relocate 160,000 people from Italy, and Greece by September 2017. The distribution of asylum-seekers is organized by a specific distribution key taking into account the size of the population (40\%), the total GDP (40\%), the average number of asylum applications over the previous four years $(10 \%)$, and the unemployment rate $(10 \%)$. The negotiations around the scheme were highly confrontational and several Eastern European Member States (especially the Czech Republic, Hungary, Rumania, and Slovakia) opposed a compulsory temporary relocation scheme. They were subsequently outvoted in the Council, but Slovakia and Hungary filed a lawsuit over the decision at the Court of Justice of the EU (CJEU) in November 2015 (Euractiv, 2015b). While the CJEU has not yet come to a judgment, Advocate General Yes Bot opined in July 2017 that the legal actions brought forward by Slovakia and Hungary should be dismissed (CJEU, 2017).

The agreed scheme suffers from an implementation deficit. As of July 2017, only about $25 \%$ of persons have been relocated (European Commission, 2017a). Only asylum-seekers from countries with an EU-wide recognition rate of $75 \%$ or higher qualify for relocation which makes it inapplicable to large numbers of asylum-seekers, particularly in Italy (Costello et al., 2017, p. 17, 20). As Poland, the Czech Republic, and Hungary have not relocated any asylum-seekers, the Commission (2017e) launched an infringement procedure against these states in June 2017. Critics further argue that the scheme does not adequately include asylum-seekers' preferences as well as their personal, family, and economic circumstances and capabilities when determining the state of relocation (Ekathimerini 2015). Similar to the Dublin system, this distribution mechanism expects asylum systems across the EU to provide protection standards and access to welfare on a comparable level. Yet, case law from both the CJEU and the European Court of Human Rights (ECtHR) has demonstrated that some Member States fail to provide even basic standards (CJEU, 2011; ECtHR, 2014). 
The temporary emergency relocation system diverts from the logic of the Dublin regulation and may be seen as a first effort by the EU towards sharing the responsibility for refugees among Member States. Given its temporary nature, it fails to establish a longer-term sustainable alternative to Dublin. As a result, in December 2015 deliberations began in the Council on a permanent relocation scheme based on the criteria of the temporary scheme outlined above (Bauböck, this volume; Thielemann, this volume; Zaun, this volume). However, by early 2016 the talks were aborted as the opposition to such measures prevailed. As an alternative, the Commission launched a proposal for a "Dublin plus" regulation. Dublin plus maintains existing rules but includes a "corrective fairness mechanism", as a result of which refugees could be redistributed in times of crisis to take the pressure off 'frontline' states (2016b). Yet, this proposal also faces very substantial opposition among a majority of member governments. Consequently, the idea of 'flexible solidarity' was promoted by the Visgrad countries at the European Council at Bratislava in September 2016 (cf. Ministry of the Interior of the Republic Poland, 2016). According to this proposal, the distribution of refugees would be voluntary. While some Member States could take in refugees, others could instead contribute financial support or expertise. It remains to be seen in which direction a future agreement will go- if it will be adopted at all.

After the pictures of drowned refugees had dominated the press for several months, EU Member States agreed on a European Resettlement Scheme in July 2015. The core of the agreement is to resettle 22,504 persons in need of international protection. Resettlement is understood as the process of admitting displaced people in need of protection from outside the EU to the Member States. The aim of such a resettlement scheme is to prevent refugees from taking dangerous paths across the sea or risking their lives by exposing themselves to smugglers. The European Resettlement Scheme is a voluntary agreement by which each Member State agreed to resettle a specific number of people in need through national and multilateral schemes. This led to considerable differences between the Member States in terms of selection criteria, length of procedures, or number of places. By April 2017, around 15,500 displaced people have been resettled to 21 Member States - representing around two thirds of the agreed target (European Commission, 2017a). In July 2016, the European Commission (2016c) proposed a permanent framework with a unified procedure for resettlement across the EU. The Commission apparently seeks to use it as a tool for persuading partner countries to agree on joint resettlement programmes on the basis of the 1:1 scheme along the lines of the EU-Turkey statement (Menéndez 2016, p. 406).

External dimension of the response - EU-Turkey Statement 
Confronted with the relative failure of the internal measures taken to solve the challenges of the crisis, the EU simultaneously tried to find external solutions. The EU-Turkey Statement of 18 March 2016 that is at the heart of this strategy (Slominski and Trauner, this volume) contains the following key aspects: (1) as of 20 March 2016 new irregular migrants entering Greece through Turkey have been returned to Turkey. This applies to all migrants who have either not applied for asylum or whose applications have been declared "unfounded" or "inadmissible". (2) A 1:1 resettlement scheme: for every Syrian being returned to Turkey from Greek islands, another Syrian will be resettled from Turkey to the EU taking into account the UN Vulnerability Criteria" (EU-Turkey Statement Art. 2; Council, 2016). The maximum number of people who will be returned through this mechanism is 72,000 . (3) Turkey promised to take any necessary measures to prevent new sea or land routes from Turkey to the EU. (4) In return, the EU has promised Turkey 1) visa liberalization provided that Turkey takes all the necessary steps to fulfil the remaining requirements, 2) disbursement of 3 billion Euros under the "Facility for Refugees in Turkey" fund and an 3) additional funding of 3 billion Euros, which will both be spent on specific projects aiming to help Syrian refugees in Turkey, 4) further negotiations and work on the upgrading of the Customs Union and the resumption and 5) extension of Turkey's accession negotiations to the EU.

Observers have credited the EU-Turkey Statement for the substantial reduction of refugees entering Greece via Turkey. In fact, arrivals in Greece dropped by 98\% between 2015 and 2016 and registered deaths and missing persons in the Aegean Sea went down by 94\%. The relative impact of the EU-Turkey Statement has, however, been questioned since it concurred with the closure of the Western Balkans route, coverage of poor reception conditions in Greece, and the introduction of internal border checks by some EU countries (Koenig and Walter-Franke, 2017, p. 4). Moreover, monthly arrivals in Greece had been declining prior to the EU-Turkey Statement already (Spijkerboer, 2016). One reason for this might be the approaching winter and the deteriorating weather conditions. Furthermore, the low number of returns $(1,826)$ under the EUTurkey Statement to date show that it did not have impact of scale (European Commission, 2017f, p. 2; Slominski, and Trauner, this issue).

Many criticisms can be levelled against the EU-Turkey Agreement. (1) Doubts have been raised whether asylum protection in Turkey is in accordance with international standards. Although there was a reform of the asylum law in 2013 by which Syrians are now considered under temporary protection and thereby have been granted more rights, non-Syrians are still not granted refugee status and the protection of their rights is in danger. Turkey applies the 1951 Geneva Convention and not the 1967 Protocol, thus only recognising refugees coming from 
Europe (Peers and Roman, 2016). In addition, Human Rights Watch (2016) published reports claiming that Turkish border guards shoot at refugees trying to cross the border, and Amnesty International (2016a) reported that large numbers of Syrians have been removed to Syria. (2) The legal obstacles of returning refugees to Turkey were (partly) solved by declaring Turkey a safe third country, a practice that can be considered problematic (see below), and can now be seriously disputed on the basis of the steps taken after the failed coup in July 2016 (Menéndenz, 2016, p. 410). (3) By making the deal with Turkey such a central element of the EU response to the crisis, the Union has risked to become considerably dependent on Turkey, and thus susceptible to blackmail by a leader with clear authoritarian leanings. The Turkish government's threats of reviewing the EU-Turkey Statement during the diplomatic row with the Netherlands surrounding the constitutional referendum seems to be a case in point for Turkey's enhanced leverage. (4) The situation in Greece is not covered coherently. The agreement does not involve refugees who entered Greece before 20 March 2016 - more than 46,000 migrants according to the latest Greek estimates at the time of the deadline. In early May 2017 the UNHCR (2017) estimated that nearly 13,000 people were still stuck on the Greek islands in dire conditions and with unclear prospects (cf. Amnesty International, 2017, pp. 22-26). (5) The speed of resettlement has been slow. Between April 2016 and March 2017 3,656 Syrians were resettled from Turkey to the EU. At this pace, it would take the EU around 13 years to resettle all Syrians it promised to (Koenig and Walter-Franke 2017: 5). (6) The 'EU-Turkey statement' is not legally binding and has not been adopted as part of the EU architecture. It is a political deal issued by the heads of state and government of the EU Member States and Turkey. Therefore, EU institutions cannot be held accountable for it which circumvents the usual checks and balances present in the EU framework, such as scrutiny of the CJEU (Carrera et al., 2017). Moreover, merely some elements, i.e. those regarding the return of migrants, are founded on binding readmission agreements. The statement became a blueprint for similar deals, notably with Afghanistan and Mali. As a result, they are not subject to EP scrutiny or judicial review by the CJEU. Therefore, people directly affected by these agreements cannot contest them in front of the EU courts (Koenig and WalterFranke, 2017, p. 2; Carrera et al., 2017).

The longevity of the EU-Turkey Statement may be questioned as the 'carrots' of visa liberalization and accession have mostly been put on ice following the repressive backlash in Turkey and also in view of the mounting threats by the Turkish government to abort the agreement.

External \& Internal dimension of the response - Safe Countries of Origin 
In September 2015 the Commission proposed a regulation establishing a common EU list of safe countries of origin. ${ }^{4}$ This list is supposed to initially comprise seven countries whose nationals account for around $17 \%$ of the total number of asylum applications filed in the EU: Albania, Bosnia and Herzegovina, Kosovo, the Former Yugoslav Republic of Macedonia, Montenegro, Serbia and Turkey. The goal is to "accelerate" asylum applications from citizens of countries considered 'safe'. At present, safe countries of origin are defined by national uncoordinated lists. This is likely to have contributed to different recognition rates of comparable asylum applications (EP, 2017, p. 3-5).

It is unclear how the fast-track approach is supposed to work in practice if Member States are still obliged to carry out an individual examination complying with the basic guarantees established in Chapter II of the asylum procedures directive in order to give the applicant the chance to disprove the assumption of safety. Granting protection to a citizen from an alleged safe country of origin is possible. However, in such case the applicant is required to rebut the presumption of safety and demonstrate the individual need for protection (EP, 2017, p. 4).

ECRE (2015) has suggested that the proposed regulation will in practice tend to considerably curtail asylum-seekers' rights to appeal a negative decision and to lawfully remain in the country where an application is lodged during a pending appeal. A standardized EU list may consequently lead to harmonization on the lowest common denominator in protection standards (also cf. Amnesty International, 2015).

It is highly questionable whether Turkey in particular can be regarded as a safe country of origin. In 2014, the percentage of well-founded asylum applications from Turkey in the EU amounted to over 23\% (European Commission, 2017b). The EU-Turkey Statement suggests that "all new irregular migrants crossing from Turkey into Greek islands" are returned to Turkey "in full accordance with EU and international law", citing the asylum procedures directive. However, serious criticism has been raised on applying the concept to Turkey based on evidence of increased push-back practices, serious obstacles for asylum-seekers including torture and degrading treatment, and the fact that Turkey applies the 1951 Geneva Convention to refugees originating from Europe only (Peers and Roman, 2016). Additionally, the numbers of asylum applications from Turkish citizens in Europe have also increased since the failed coup d'état of July 2016 when the government adopted severe measures against military personnel, judges, and some government officials (Süddeutsche Zeitung, 2017).

\footnotetext{
${ }^{4}$ The concept of a 'safe country of origin' is used in migration management to define countries which, based on their stable democratic system and compliance with international human-rights treaties, are presumed safe to live in (Official Journal, 2013, p. L180/64).
} 
External dimension of the response - preventing irregular migration through border controls, trafficking and smuggling

Due to the limited competences and capacities of Frontex to protect the EU external borders, the Commission launched a proposal for a European Border and Coast Guard Agency (EBCG) in December 2015 that entered into force in October 2016. The new agency has been characterized as 'a milestone in the history of European border management' (Avramopoulos, 2016). The EBCG has enhanced resources, an enlarged mandate and greater independence vis-à-vis Member States as compared to FROTEX. For example, it carries out regular mandatory vulnerability assessments of Member States' border management capabilities. Where deficiencies are detected and not acted upon by Member States, the EBCG's 'right to intervene' may be invoked whereby the Council may decide by qualified majority to dispatch border guards to a Member State, even against its will. Although some noticeably integrative steps have been taken (Niemann and Speyer, this issue), critics have argued that the EBCG fails to establish a common European border management, inter alia since substantial responsibilities (e.g. the implementation of border controls) have been left to the Member States (Carrera and den Hertog, 2016). Moreover, the EBCG is the result of strong power asymmetries between strong regulating states in Northern Europe and weak regulating border states in Southern Europe (Ripoll Servent, this issue).

The Commission's Agenda on Migration has identified the fight against smuggling and trafficking in human beings as a priority. In June 2015, it launched a military naval operation (formerly "EUNAVFOR MED”, now called "SOPHIA") which has two main goals: disrupting trafficking and smuggling and preventing further loss of life in the Mediterranean high seas. To achieve that, it seeks to identify, seize, and dispose of vessels used by migrant smugglers. According to a leaked EU internal document, "SOPHIA" had reduced the number of migrants using the central Mediterranean route by $9 \%$ by the end of 2015 , and achieved significant results in its first six months (EEAS, 2016, p. 3-4). The House of Lords (2016, p. 3) concluded that the mission does not "in any meaningful way deter the flows of migrants, disrupt the smugglers' networks, or impede the business of people smuggling in the central Mediterranean route".

Moreover, the EU has tripled its budget on "Triton" and "Poseidon" since June 2015, thus reverting the cuts from the above-mentioned abolition of Mare Nostrum (Menéndez, 2016, p. 397). Both operations focus on border control and surveillance, with Triton operating close to the Italian and Poseidon at the Greek coast. Since providing help in emergencies is one of the operations' objectives, many lives of refugees in distress at sea could be saved - up to 122,000 until September 2015 alone, according to the European Commission (2015b, p. 1). However, although both areas of operation have been heavily expanded since June 2015, Triton and 
Poseidon only intervene in situations near the EU's external borders. In contrast to the former operation "Mare Nostrum" which ended in 2014, Triton does not operate as close to the Libyan coast where many refugees lost their lives in 2015. In addition, substantial human rights concerns regarding the EU's external border policy and operations in the Mediterranean haven been raised (e.g. Moreno-Lax, this volume).

\section{External dimension of the response - Trust funds}

To diminish further migration flows, the EU has built up several trust funds of which three are the most important:

(1) The EU Regional Trust Fund for Syria has been established in December 2014 to meet the regional challenges of the Syrian crisis and focuses on the aid for Syrian refugees within Syria and neighbouring countries, namely Iraq, Jordan, Lebanon, and Turkey. It aims to help 1.5 million Syrian refugees by providing basic necessities such as health care, education, child protection, water infrastructure, as well as improved economic opportunities. By December 2016, 767 million Euro, provided by 22 Member States, Turkey and the EU budget, have been allocated to relevant programmes (European Commission, 2016d). In June 2017 the target of one billion Euros was surpassed (European Commission, 2017g).

(2) The Emergency Trust Fund for Africa, established at the Valletta Summit in November 2015, aims to address the root causes of destabilization, forced displacement, and irregular migration. The beneficiaries of the Trust Fund are the countries of the Sahel region, the Lake Chad area, the Horn of Africa, and the North of Africa. The scope of the Fund amounts to 2.8 billion Euro from the EU, its Member States, and other donors. Programmes prioritize economic and equal opportunities, resilience, security and development (European Commission, 2017c).

(3) The Bêkou Trust Fund for the Central African Republic, established in July 2014, funds postconflict and transition-related support activities, such as employment, health, or refugee support. Its initial budget amounts to 64 million Euro as provided by the EU, France, Germany, and the Netherlands (European Commission, 2017d).

The need for long-lasting and sustainable support for the neighbouring countries of Syria can be drawn from looking at the numbers. Whereas Lebanon has hosted 1.1 million Syrian refugees in addition to about 450,000 refugees from Palestine in 2015, at the same time 2.7 million refugees have been counted in Jordan, including over 2 million Palestinians and about 665,000 Syrians. Furthermore, the refugee population in Turkey has risen to more than 3 million in 2016 (Amnesty International 2016b, pp. 9-10). These countries are in severe need of financial and operational support. The EU Trust Funds are therefore one (relatively substantial) measure of 
European development policy. Den Hertog (2016, p. 13) raises suspicion that the actual arrangements and priorities under these funds might rather serve the EU's short-term security interests.

Towards a centralization of EU asylum policy?

Harmonisation of asylum policies in the EU has barely led to the implementation of minimum protection standards in the EU, let alone common standards (Ripoll Servent and Trauner 2014; Den Heijer et al., 2016). In the wake of the crisis, it became clear that the lack of harmonization of asylum legislation had (significantly) contributed to the crisis, not least in terms of prompting differing/diverging migratory pressures across the EU. Since late 2015, the Commission has reacted by launching proposals for a third generation of EU asylum related legislation, with the new Dublin IV regulation at the heart, but also important proposals on asylum procedures, qualification, reception conditions, Frontex/EBCG, EASO, safe countries or origin, resettlement, and EURODAC. The Commission obviously favours a noticeable centralization and harmonization of EU policy. Several legislative acts hitherto enshrined in directives will now turn into regulations, e.g. the asylum procedures directive (2013/32/EU) and the qualification directive (2011/95/EU). Several measures highlight the relatively ambitious nature of the Commission's proposals: (1) accelerated border procedures would become mandatory; (2) systematic fingerprinting could be ensured coercively; and (3) the EASO could be modelled along similar lines as the EBCG (with a mandatory pool of experts and a "right to intervene") (cf. e.g. Menéndez, 2016; but cf. Ripoll Servent, this volume). However, Member State officials have been pointing out that, on issues such as Dublin, asylum procedures, and qualification, prolonged and tough negotiations are to be expected (Interview NAT-1, NAT-2, NAT-3).

The previous sections have demonstrated that the EU's response to the crisis has been more comprehensive than commonly perceived. However, still much depends on the degree to which the Commission's proposals will be agreed and eventually implemented. So far, the EU has made most (effective) efforts with regard to limiting migration flows into Europe, while progress in terms of a fair and long-term distribution of refugees and addressing the root causes of migration is rather mixed. In addition, security-oriented measures have dominated over measures to ensure the protection of human and civil rights of asylum-seekers.

\section{Contribution of this Special Issue}

After having presented and assessed the EU's response to the crisis, we now turn to the contribution of the Special Issue. We will first summarise the core arguments of the contributions 
to this Special Issue and discuss how they contribute to our understanding of the crisis, before we turn to its overall contribution to the understanding of EU policy-making and EU integration as well as to theories of European integration.

\section{Explaining the relatively poor internal response to the crisis}

The Special Issue provides an explanation for the relatively poor internal response to the crisis especially when it comes to the introduction of mechanisms to ensure responsibility-sharing.

According to Thielemann, the absence of effective cooperation on this issue can be explained through the public good characteristics of asylum cooperation which have influenced EU decision-making in this area for the last eighteen years. States consider refugee protection a zerosum game and hence have almost no incentives to cooperate in this area. This entails moral hazard dynamics and situations where some big Member States - such as Germany, that can make an impact of scale and have the capacity of receiving more refugees - take larger shares, while smaller Member States engage in free-riding and refrain from contributing to responsibilitysharing.

Drawing on liberal intergovernmentalism, Zaun shows that the introduction of permanent refugee quotas failed due to asymmetrical interdependence and the presence of Suasion Game dynamics. While only few Member States received large numbers of asylum applications and perceived the quota system as an opportunity to divert refugee flows, the vast majority of Member States only had a low intake of asylum-seekers and were not ready to engage in responsibility-sharing as this would have implied receiving a larger share. The growing influence of populist parties both in top-recipient countries such as Germany, Austria, and Sweden, as well as the fact that populist parties were in government in the Visegrad countries further politicised the issue and account for the confrontational style of debates at the EU level.

Jachtenfuchs and Genschel point out that certain public goods (Thielemann, this volume) and bargaining problems (Zaun, this volume) are, in fact, endogenous to a certain substantive area of integration, namely to core state powers. Their key argument is that the integration of core state powers involves the allocation of limited public resources rather than the imposition of potentially unlimited public rules on private market actors. This implies tough distributive conflicts (since every Euro can only be spent once) and higher politicization (because citizens care for their collective patrimony). Hence, the problem is that Member States seek increased European integration without a system of 'burden-sharing' (i.e. mutual insurance). This does not work in core state powers except for very benign circumstances, i.e. no refugees coming in the first place. 


\section{Responsibility-shifting and externalising refugee flows: A viable solution?}

Given the absence of an effective response to internal redistributive challenges, the EU needed to find alternative venues to respond to pressures resulting from the inflow of asylum-seekers. These include an externalisation of refugee flows. The adoption of the ECBG was a clear step into this direction, as the strengthening of border protection implies responsibility-shifting towards third countries outside the EU. Arguably, the EU institutions were able to take much stronger actions in the external dimension of EU asylum policy than internally, because there was a common interest among the Member States for more integration. More integration in border management would redistribute asylum-seekers to third countries, whereas the introduction of permanent refugee quotas would have implied an internal redistribution from which some Member States would obviously benefit more than others.

Applying neofunctionalist explanations, Niemann and Speyer demonstrate that the crisis revealed the existing dysfunctionalities of the system, especially between a supranational Schengen and an intergovernmental external border regime and has thus acted as a catalyst for further sovereignty transfers in the area of border protection and the introduction of the ECBG. Several path dependencies such as the political and sunk costs of Schengen disintegration blocked the possibility for a spillback. Supranational institutions, socialized civil servants, transnational promigrant interest groups, and European business associations contributed to translating these pressures into an increased breadth and depth of integration in this area, while falling short of reaching a genuinely supranational solution. However, arguing counterfactually, without the crisis and the severe pressures on the Schengen regime, this policy reform would not have occurred in the nearer future, as Member States had usually been reluctant to transfer substantive powers to a shared border agency in this sensitive area of national sovereignty.

Yet, as Ripoll Servent underlines, delegation towards the EBCG and EASO was not a symmetrical process in which all Member States participated to the same extent. Drawing on Principle-Agent arguments, she instead demonstrates that these agencies have been strengthened to address the severe and continuous deficiencies of the asylum and border protection systems of weak regulating states, particularly Italy and Greece. These agencies are now supposed to close regulatory gaps and enforce policies on the ground in weak regulating states. The crisis has therefore reinforced the power asymmetries between strong and weak regulators as it led to decisions through which the regulatory model of the strong regulators in the North will be imposed on the weak regulators in the South, which previously had a more informal asylum regime in place. Thus, Ripoll Servent uncovers the complex forms of agencification in this policy 
area, drawing attention to cleavages between the different Member States of whom only some act as principals delegating to EU institutions to control their fellow Member States.

Again, this approach obviously fails to address the key deficiencies of the CEAS identified above. Instead, it perpetuates the North's attempts to shift responsibility towards the South by, first, establishing functioning asylum systems in 'frontline' states to make them receive more asylumseekers and, second, introducing stronger border protection in these states which eventually shifts the responsibility to countries outside of Europe.

While responsibility was shifted towards other Member States and third countries, Member States could not shift the blame for higher application numbers to the inefficiencies of the EU. Even though European publics these days are often assumed to be easily manipulated by Eurosceptic politicians who shift the blame for national policy failure to the EU, Harteveld et al. (this volume) argue that publics see through the blame-game of domestic politicians and are aware that the poor crisis response cannot be blamed solely on the EU but that Member States are also partially responsible. They demonstrate that the number of asylum applications in the EU and the media attention this generates primarily affect Euroscepticism, whereas the number of asylum applications into each Member State affects attitudes towards national institutions and governments.

\section{Informal venues and new policy frames as a means of bypassing humanitarian responsibilities}

To bypass its humanitarian responsibilities, the EU has increasingly relied on informal decisionmaking structures and new policy frames when externalising refugee flows.

Slominski, and Trauner show that although the crisis has not fundamentally changed return policies in Europe, it has influenced them in two significant ways: first, EU Member States are more determined to render return policies more effective through closing loopholes and interpreting the existing rules more rigorously. Second, the crisis has contributed to a stronger reliance on informal patterns of cooperation with the aim of evading institutional and legal constraints. The EU-Turkey Statement was a case in point. It externalised migration control, shifting the responsibility to assess asylum claims onto a third country (Turkey), and it informalized return policy. The 'non-usage' of the EU, they conclude, hence provided avenues for bypassing and undermining institutional and legal constraints that a usage of the EU's supranational architecture would have implied.

Although the EU has developed an increasing number of safeguards to protect the human rights of migrants, there is clearly a tendency to circumvent the established institutional context to 
pursue restrictive and even human rights violating practices. Member States, it seems, tend to use perceived legal grey-zones to ensure greater flexibility to respond to new needs.

Moreno-Lax also provides evidence of this constant struggle of EU actors to exploit perceived legal grey-zones and normative gaps, often by reframing the challenges to be addressed and thus the acceptable responses. She shows that - under pressures to comply with human rights norms - Frontex and related border operations have relied increasingly on the invocation of human rights to de facto curtail the rights of migrants trying to enter EU territory. Search and rescue operations which in fact have few other goals than preventing migrants from accessing EU territory are now framed as life-saving devices.

The EU as the lesser evil? Comparing global and regional responsibility-sharing and reflecting on potential solutions

While the EU's internal response to rising numbers of asylum applications was relatively poor, the fact that it came up with a temporary relocation mechanism shows that the EU is still much more capable of ensuring some forms of responsibility-sharing than the UN. The UN Global Compact on Refugees underlines the need for cooperation, yet, it does not make any concrete suggestions on how to tackle it.

While at the European level there are few incentives for cooperation, Bauböck reminds us that the EU context is still the single most favourable context for cooperation on these issues and much more favourable than the United Nations, precisely because of functional and normative pressures resulting from Schengen and the persistence of cooperation between EU Member States. To ensure a distribution that is both fairer for states and ensures that the largest number of these in need of protection receive it, Bauböck supports suggestions for tradable refugee quotas (Fernández-Huertas Moraga and Rapoport, 2014; Jones and Teytelboym, 2016) that pay significant consideration also to the preferences of refugees. Otherwise, such a system is likely to fail in an area of free movement like Schengen. The advantage of having tradable quotas, moreover, is that countries that completely oppose receiving refugees still contribute. However, in contrast to suggestions currently debated at the EU level, Bauböck proposes that the price per refugee should not be fixed, but ought to reflect the costs the exclusionary preferences of some Member States have on the other Member States.

\section{The bigger picture: What the CEAS crisis tells us about the state of European integration and its theories}

Scholars of European integration increasingly take the view that theories used for conceptualising European integration tend to be complementary rather than competing with each other (Dietz 
and Wiener 2009; Ioannou et al. 2015). This view is confirmed through the analyses of the Special Issue.

Beyond the broad distinction between some approaches advanced in this volume being more explanatory - liberal intergovernmentalism (Zaun), neofunctionalism (Niemann and Speyer), collective action (Thielemann), principal-agent analysis (Ripoll Servent), political attitude research (Harteveld et al.), the comparative analysis of core state powers (Genschel and Jachtenfuchs) and others being more interpretative (Slominski and Trauner) and normative (Moreno-Lax as well as Bauböck), one can also detect different "domains-of-application" (Jupille et al., 2003, p. 22) within these broad distinctive categories. In the following, we will focus on the different domains of application, i.e. the specific foci, of each of the explanatory approaches.

All of these approaches explain the absence of integration, yet, they highlight different aspects of it. Collective action can best explain the basic underlying incentive structures which explain both ineffective cooperation and why some Member States are ready to take on disproportional responsibilities. But collective action approaches do not zoom into domestic preference formation and EU negotiation processes to show how they interlink and how power differentials between Member States impact on EU legislative output. This is instead done by liberal intergovernmentalism.

The Special Issue shows that also the old antagonists, liberal intergovernmentalism and neofunctionalism are compatible. The key difference is that liberal intergovernmentalism opens the black box of domestic preference formation and closely investigates national constraints as well as power dynamics between actors in EU negotiations whereas neofunctionalism instead focuses on the role of the supranational actors (especially the European Commission) and functional pressures used by these actors to promote policy innovation and overcome (minor) constraints. While it disentangles these constraints and Council decision-making dynamics to a lesser extent, it provides deeper insights into the other side of the coin, namely the strategic action of supranational actors.

Principal agent theories also focus on motivations and preferences and try to explain policy outcomes. However, their focus is on explaining instances where powers are delegated to EU institutions (in the case investigated here only those of the weak regulators whose compliance with EU policies is thus being ensured). In future research, it would be interesting to see if this type of asymmetric delegation that Ripoll Servent finds on both EASO and the ECBG is part of a wider trend across policy areas or just a specific characteristic of EU asylum policy-making. 
The comparative analysis of core state powers, in fact, might suggests this. It assumes that EU policy-making across different areas of core state powers is highly sovereignty-relevant and has important redistributive implications which explains Member States cautiousness to centralize these policies at the EU level. The analysis of core state powers therefore provides the bigger picture, highlighting that what we find for EU asylum policies actually applies to a larger group of policy areas which include also, for instance, monetary policies. This explains why decisionmaking in the Eurozone and the CEAS crisis share significant communalities.

Investigating the crisis also supports recent findings that European cooperation, particularly in the area of core state powers, does not always equal European integration. Instead, European cooperation can occur outside of the common EU structures and institutions and take more intergovernmental forms. This strongly resonates with similar empirical findings of proponents of the so-called "New Intergovernmentalis" (Bickerton et al., 2015). It seems that Member States are strongly aware of the national and international (legal) constraints they themselves and their fellow Member States are subject to. Where common positions are easy to find, Member States happily act within the EU framework as the case of the EBCG has demonstrated. Where these cannot be found (e.g. on the redistribution of refugees and responsibility-sharing), alternative venues are searched for. A point in case is the EU-Turkey Statement which was conceived by a few Member States with the support of the Commission. As it was not decided within the EU institutional framework, it is not considered an authoritative EU act by the CJEU. This is highly problematic. Scholars have shown that the EU legal and institutional framework has provided additional constraints for policy-makers who aim to restrict domestic asylum policies (Slominksi, 2013; Zaun, 2017, p. 24). By opting for new intergovernmental settings, Member States are again able to evade these constraints and legal guarantees and adopt policies which are normatively highly questionable (see Slominski and Trauner; Moreno Lax). Further research should address whether this deliberate non-use of EU institutional structures is merely a characteristic of crisis situations or perhaps part of a wider development in areas of core state powers or even beyond.

\section{References}

Amnesty International (2015) EU: Action not words needed to end suffering of thousands. 14 July. «https://www.amnesty.org/en/latest/news/2015/09/eu-action-not-words-needed-atjha-to-end-suffering-of-thousands/».

Amnesty International (2016a) Turkey: Illegal mass returns of Syrian refugees expose fatal flaws in EU-Turkey Statement, 1 April. «https://www.amnesty.org/en/pressreleases/2016/04/turkey-illegal-mass-returns-of-syrian-refugees-expose-fatal-flaws-in-euturkey-deal/». 
Amnesty International (2016b) Tackling the global refugee crisis. From shirking to sharing responsibility, 18 «https://www.amnesty.org/en/documents/pol40/4905/2016/en/».

Amnesty International (2017) A Blueprint for Despair, February. «http://www.amnesty.eu/content/assets/Reports/EUTurkey_Deal_Briefing_Formatted_Final_P4840-3.pdfi».

BBC News (2016a) Migrant crisis: Migration to Europe explained in seven chartes. 4 March 201. « http://www.bbc.co.uk/news/world-europe-34131911».

BBC News (2016b) Why is EU struggling with migrants and asylum? 3 March. « http://www.bbc.co.uk/news/world-europe-24583286».

Bickerton, C. J., Hodson, D., Puetter, U. (2015) 'The New Intergovernmentalism: European Integration and the Post-Maastricht Era.' Journal of Common Market Studies, Vol. 54, No. 4, pp. 703-722.

Carrera, S. and den Hertog, L. (2016) 'A European Border and Coast Guard: What's in a name?' CEPS Paper in Liberty and Security in Europe, No.88.

Carrera, S., den Hertog, L., Stefan, M. (2017) It wasn't me! The Luxembourg Court Orders on the EU-Turkey Refugee Deal. CEPS Policy Insights No. 15. «https://www.ceps.eu/system/files/EU-Turkey\%20Deal.pdf».

Collet, L. (2015) The Asylum Crisis in Europe: Designed Dysfunction. « http://www.migrationpolicy.org/news/asylum-crisis-europe-designed-dysfunction».

Costello, C., Guild, E., Moreno Lax, V. (2017) Implementation of the 2015 Council Decisions Establishing Provisional Measures in the Area of International Protection for the Benefit of Italy and Greece. Study for the LIBE committee, March. «http://www.europarl.europa.eu/RegData/etudes/STUD/2017/583132/IPOL_STU(2017)5 83132_EN.pdf».

Council (2016) EU-Turkey statement, $18 \quad$ March 2016. «http://www.consilium.europa.eu/en/press/press-releases/2016/03/18-eu-turkeystatement/».

CJEU (2011) Joined Cases C-411/10 and C-493/10 N. S. v Secretary of State for the Home Department and M. E. and Others v Refugee Applications Commissioner and Minister for Justice, Equality and Law Reform, 21 December. «http://eur-lex.europa.eu/legalcontent/EN/ALL/?uri=CELEX:62010CJ0411».

CJEU (2017) Advocate General's Opinion in Case C-643/15 and C-647/15 Slovakia and $\begin{array}{llll}\text { Hungary } & \mathrm{v} & \text { Council, } & 26\end{array}$ «https:// curia.europa.eu/jcms/upload/docs/application/pdf/2017-07/cp170088en.pdf».

Den Hertog, Leonhard (2016). EU budgetary responses to the 'refugee crisis'. CEPS Paper in Liberty and Security in Europe, 93. «https://www.ceps.eu/system/files/LSE\%20No\%2093\%20LdH\%20on\%20EU\%20Budgetar y $\% 20$ Responses $\% 20$ to $\% 20$ the $\% 20$ Refugee $\% 20$ Crisis.pdf».

Den Heijer, M, Rijpma, J., Spijkerboer, T. (2016) 'Coercion, prohibition and great expectations: The continuing failure of the Common European Asylum System'. Common Market Law Review, Vol. 53, No.3, pp.607-642.

Diez, T. and Wiener, A. (2009) 'Introducing the mosaic of integration theory', in A. Wiener and T. Diez (eds), European Integration Theory, 2nd edn, Oxford: Oxford University Press, pp. 1-22. 
ECRE et al. (2016). The implementation of the hotspots in Italy and Greece. «http://www.ecre.org/wp-content/uploads/2016/12/HOTSPOTS-Report-5.12.2016..pdf».

EEAS (2016) EUNAVFOR MED Op SOPHIA - Six Monthly Report, Operation Comander, Op SOPHIA (EEAS), 29 January. «https://wikileaks.org/eu-military-refugees/EEAS/EEAS2016-126.pdf».

Ekathimerini (2015) EU's refugee relocation scheme 'not enough,' says UNHCR chief, 12 August. «http://www.ekathimerini.com/202427/article/ekathimerini/news/eus-refugee-relocation-schemenot-enough-says-unhcr-chiefi.

Euractive (2015a) Germany suspends Dublin Agreement for Syrian Refugees, 26 August. «https://www.euractiv.com/section/economy-jobs/news/germany-suspends-dublinagreement-for-syrian-refugees/».

Euractiv (2015b) Slovakia takes EU to Court of migrant quotas. «https://www.euractiv.com/section/central-europe/news/slovakia-takes-eu-to-court-overmigrant-quotas/».

European Commission (2015a) Communication from the Commission to the European Parliament, the Council, the European Economic and Social Committee and the Committee of the Regions. A European Agenda on Migration, 13 May. «https://ec.europa.eu/homeaffairs/sites/homeaffairs/files/what-we-do/policies/european-agendamigration/background-

information/docs/communication_on_the_european_agenda_on_migration_en.pdf».

European Commission (2015b) Managing the refugee crisis: Immediate operational, budgetary and legal measures under the European Agenda on Migration, 23 September. «http://europa.eu/rapid/press-release_IP-15-5700_en.htm».

European Commission (2016a) Communication from the Commission to the European Parliament and the Council: Progress report on the implementation of the hotspot approach in Greece, 4 March. «https://ec.europa.eu/home-affairs/sites/homeaffairs/files/what-wedo/policies/european-agenda-migration/proposal-implementation-

package/docs/communication_20160304_progress_report_on_the_implementation_of_the_ hotspots_in_greece_en.pdf».

European Commission (2016b) Proposal for a Regulation ... establishing the criteria and mechanisms for determining the Member State responsible for examining an application for international protection lodged in one of the Member States by a third-country national or a stateless person (recast), 4 May. «http://eurlex.europa.eu/legalcontent/EN/TXT/?qid=1465212426716\&uri=CELEX:52016PC0270».

European Commission (2016c) Proposal for a Regulation ... establishing a Union Resettlement Framework and amending Regulation (EU) No 516/2014 of the European Parliament and the Council, Brussels, 13 July. «https://ec.europa.eu/home-affairs/sites/homeaffairs/files/whatwe-do/policies/european-agenda-migration/proposal-implementationpackage/docs/20160713/resettlement_system_en.pdf».

European Commission (2016d) EU Syria Trust Fund, 6 December. «http://europa.eu/rapid/press-release_IP-16-4270_en.htm».

European Commission (2017a) Annex to the Report from the Commission to the European Parliament, the European Council and the Council. Fourteenth report on relocation and resettlement. «https://ec.europa.eu/home-affairs/sites/homeaffairs/files/what-wedo/policies/european-agenda-

migration/20170726_fourteenth_report_on_relocation_and_resettlement_annex1_en.pdf». 
European Commission (2017b) An EU 'Safe Countries of Origin' List. «https://ec.europa.eu/home-affairs/sites/homeaffairs/files/what-we-do/policies/europeanagenda-migration/background-information/docs/2_eu_safe_countries_of_origin_en.pdf»».

European Commission (2017c) EU Emergency Trust Fund for Africa. «https://ec.europa.eu/europeaid/regions/africa/eu-emergency-trust-fund-africa_en».

European Commission (2017d) EU Trust Fund "Bêkou". «https://ec.europa.eu/europeaid/trust-fund-bekou_en».

European Commission (2017e) Relocation: Commission launches infringement procedures against the Czech Republic, Hungary and Poland. 14 June. «http://europa.eu/rapid/pressrelease_IP-17-1607_en.htm».

European Commission (2017f) Operational implementation of the EU-Turkey Statement, 10 July. «https://ec.europa.eu/home-affairs/sites/homeaffairs/files/what-wedo/policies/european-agenda-migration/press-material/docs/state_of_play_-_euturkey_en.pdf».

European Commission (2017g) EU Syria Trust Fund, 20 June. «http://europa.eu/rapid/pressrelease_IP-17-1593_en.htm».

ECtHR (2014) CASE OF TARAKHEL v. SWITZERLAND (Application no. 29217/12), 4 November. «http://hudoc.echr.coe.int/eng?i=001-148070».

European Parliament (2017) Safe countries of origin: Proposed common EU list, February. «http://www.europarl.europa.eu/RegData/etudes/BRIE/2015/569008/EPRS_BRI(2015)56 9008_EN.pdf».

Eurostat (2017a) 1.2 million first time asylum-seekers registered in 2016, 16 March. «http://ec.europa.eu/eurostat/documents/2995521/7921609/3-16032017-BPEN.pdf/e5fa98bb-5d9d-4297-9168-d07c67d1c9e1».

Eurostat (2017b) Countries of origin of (non-EU) asylum-seekers in the EU-28 Member States, 2015 and 2016, 15 March. «http://ec.europa.eu/eurostat/statisticsexplained/index.php/File:Countries_of_origin_of_(non-EU)_asylum_seekers_in_the_EU28_Member_States,_2015_and_2016_(thousands_of_first_time_applicants)_YB17.png».

Eurostat (2015) Asylum applicants and first instance decisions on asylum applications: 2014, March. «http://ec.europa.eu/eurostat/documents/4168041/6742650/KS-QA-15-003-ENN.pdf/b7786ec9-1ad6-4720-8a1d-430fcfc55018».

Fernández-Huertas Moraga, J. and Rapoport, H. (2014) 'Tradable Refugee Quotas and EU Asylum Policy'. IZA Discussion Paper Series No. 8683.

House of Lords (2016) Operation Sophia, the EU's naval mission in the Mediterranean, 13 May. «https://www.publications.parliament.uk/pa/ld201516/ldselect/ldeucom/144/144.pdf.

Human Rights Watch (2106a). Greece: Refugee “Hotspots” Unsafe, Unsanitary, 19/05/2016, «https://www.hrw.org/news/2016/05/19/greece-refugee-hotspots-unsafe-unsanitary».

Human Rights Watch (2016b) Turkey: Border Guards Kill and Injure Asylum-seekers, 10 May, «https://www.hrw.org/news/2016/05/10/turkey-border-guards-kill-and-injure-asylumseekers».

Ioannou, D., Leblond, P., and Niemann, A. (2015), 'Introduction: European Economic Integration in Times of Crisis: Practice and Theory', Journal of European Public Policy, Vol.22, No 2, pp.155-176.

Jones, W. and A. Teytelboym (2016) 'Choices, preferences and priorities in a matching system for refugees'. Forced Migration Review, Vol.61,pp. 80-82. 
Jupille, J., Caporaso, J.A. and Checkel, J.T. (2003) 'Integrating institutions: rationalism, constructivism, and the study of the European Union', Comparative Political Studies 36(7): 7-40.

Kingsley, P. (2016) Refugee crisis: What does the EU's deal with Turkey mean?, 18 March. «https://www.theguardian.com/world/2016/mar/18/eu-deal-turkey-migrants-refugees-qand-a».

Koenig, N. and Walter-Franke, M. (2017) One year on: What lessons from the EU-Turkey 'deal'?, 17 March.«http://www.delorsinstitut.de/2015/wp-content/uploads/2017/03/20170317_EUTurkey-deal-one-year-on-NK-MW.pdf».

Menéndez, A. J. (2016) 'The refugee crisis: between human tragedy and symptom of the structural crisis of European integration'. European Law Journal, Vo.22, No.4, pp.388-416.

Ministry of the Interior of the Republic Poland (2016) Joint Statement of Ministers on establishment of the Migration Crisis Response Mechanism, 21 November. «http://www.msz.gov.pl/resource/12d5f115-0fe9-42b6-b73d-8deeea23983d:JCR».

Niemann, A. (2006) Explaining Decisions in the European Union, Cambridge: Cambridge University Press.

Official Journal of the European Union (2013) Directive 2013/23/EU on common procedures for granting and withdrawing international protection (recast), 29 June. «http://eurlex.europa.eu/legal-content/EN/TXT/PDF/?uri=CELEX:32013L0032\&from=EN».

Pastore, F., \& Henry, G. (2016) 'Explaining the crisis of the European migration and asylum regime'. The International Spectator, Vol. 51; No.1, pp.44-57.

Pauly, S., Blöser, J., Bank, K., Niemann, A. and Zaun, N. (2016), 'The EU's response to the socalled refugee "crisis"”. Political Science Applied, Vol.7, pp. 14-20.

Ripoll Servent, A., and F. Trauner (2014) 'Do supranational EU institutions make a difference? EU asylum law before and after "communitarization" '. Journal of European Public Policy Vol.21, No.8, pp.1142-62.

Slominski, P. (2013) 'The Power of Legal Norms in the EU's external border control'. International Migration, Vol. 51, No. 6, pp. 41-53.

Spijkerboer, T. (2016) Fact Check: Did the EU-Turkey Statement Bring Down the Number of Migrants and Border Deaths? Oxford Border Criminologies Blog, 28 September. «https://www.law.ox.ac.uk/research-subject-groups/centre-criminology/centrebordercriminologies/blog/2016/09/fact-check-did-eu».

Süddeutsche Zeitung (2017) Türkische Soldaten erhalten Asyl in Deutschland, 9 May. «http://www.sueddeutsche.de/politik/asyl-tuerkische-soldaten-erhalten-asyl-in-deutschland$1.3496762 »$.

Trauner, F. (2016) 'Asylum policy: the EU's 'crises' and the looming policy regime failure'. Journal of European Integration, Vol. 38, No. 3, pp. 311-325.

UNHCR (2017a) Syria Regional Refugee Response, 2 July. «http://data.unhcr.org/syrianrefugees/regional.php».

UNHCR (2017) Europe Refugee Emergency: Daily map indicating capacity and occupancy (Governmental figures), 2 May. «https://data2.unhcr.org/en/documents/download/56242».

United Nations (1951) Convention relating to the Status of Refugees. «http://www.ohchr.org/Documents/ProfessionalInterest/refugees.pdf».

Vătăman, D. (2016) 'Migration and refugee crisis'. "Challenges of the Knowledge Society”, 20-21 May 2016, Bucharest, vol. 10, pp. 544-549. 
Weber, B. (2016) 'Time for a Plan B: The European Refugee Crisis, the Balkan Route and the EU-Turkey Statement'. Democratic Policy Council, Working Paper, September. «http://www.democratizationpolicy.org/pdf/DPC_Policy_Paper_Europ_refugee_crisis_EU_ Turkey_deal.pdf».

Zaun, N. (2017) EU Asylum Policies: The Power of Strong Regulating States (Houndmills: Palgrave Macmillan). 